163. 歯と歯菱の境界抽出に関する一検討

肥後尚志小川裕司篠田之孝佐々木 嘉雄 (日本大学理工学部)

\title{
1.はじぬに
}

歯周病は歯周病菌が歯 (歯牙) と歯茥 (歯肉) の境界に侵入し、最終的に歯の喪失を招くものである。 このため、歯と歯茎の境界位置を把握することは、高齡者の歯の健康管理において特に重要である。

そこで、本文では色度図上の距離が、そのまま色の差となる $\mathrm{u}^{\prime}-\mathrm{v}^{\prime}$ 色度図(1)により、歯と歯茥の境界 を抽出(2)する基礎的実験を行ったので、以下に報告する。

\section{2. 実験}

実験のフローチャートを図 1 に示す。歯および歯茎の 撮影時の照明用光源には白色 LED を使用し、撮影には 3 板式カラーCCD カメラ (SONY 製 XC-O 0 3、解 像度 $570 \times 485$ ) を用いた。出力は R、G、B 各色 256 階調のフルカラー画像信号として出力され、画像 の大きさは $256 \times 256$ [pixel]に設定している。CCD カメラから出力された R、G、B 各信号は、画像処理ボ 一ドを介してコンピューターに入力する。

図 2 は歯と歯菱を撮影した画像である。CCD カメラ から取り出された画像の R、G、B 各信号を、XYZ 表色 系の基礎刺激に変換し、これを基に、 $\mathrm{u}^{\prime}-\mathrm{v}^{\prime}$ 色度図にお ける u'、v'值を算出する。

図 3 は白色からの各画素における $u^{\prime} 、 v^{\prime}$ 值までの距離 $\mathrm{d}$ を求め、距離ごとの画素数を数えて作成した距離七ス トグラムである。ヒストグラムは 2 つ領域 I 、II 別できる。dがより小さいIの領域は歯色を構成する領 域と考えられ、領域 II は歯茎を含むその他の領域と考え られる。I の領域では距離 $\mathrm{d}$ が増加するにつれて画素数 は減少してゆき、距離 $\mathrm{d}_{\mathrm{m}}=0.85 \times 10^{-2}$ 付近で画 素数がほぼ一定となる。そこで、この距離ヒストグラム において画素数の変化が最も小さくなる部分の距離 $\mathrm{d}_{\mathrm{m}}$ を歯と歯茎の境界示す閾值として抽出した境界線が図 4 である。歯の部分の境界抽出が行われていることが分 かる。

\section{3. おわりに}

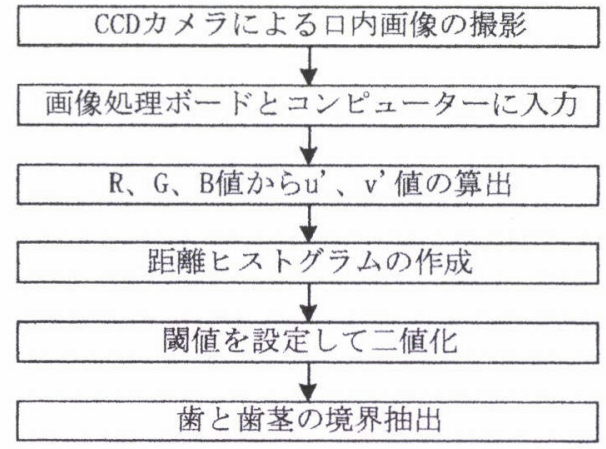

図 1 実験のフローチャート

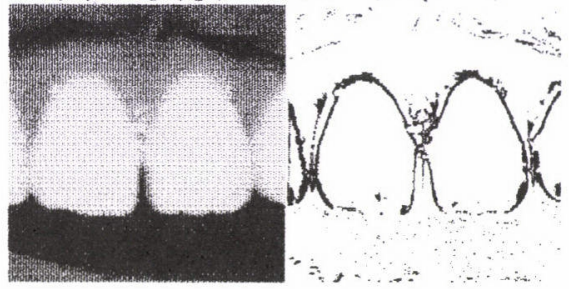

図 2 原画像図 4 境界線画像

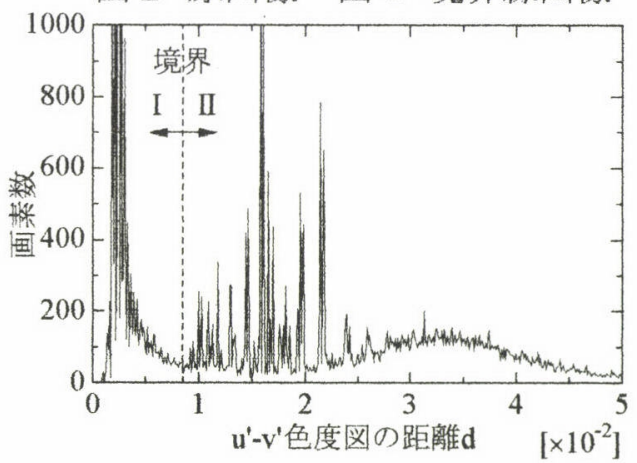

図 3 距離ヒストグラム

u'-v'色度図を用いて歯と歯茥の境界を抽出することが出来ることが分かった。しかし、この方法に ついては闇值の算定方法や、ハイライト、影など照明に関する問題等がまだあり、今後、検討していく 予定である。

\section{参考文献}

（1）例えば, 池田光男：色彩工学の基礎, 朝倉書店（1980）

(2) Rafael Gonzalez 他: Digital Image Processing, Addison Wesley (1992)

A Study of Contour Tracing between Teeth and Gums

Higo Takashi, Ogawa Yuuji, Shinoda Yukitaka, Sasaki Yoshio 